\title{
Self-management strategies of graduate employees to enhance work engagement
}

\begin{tabular}{|c|c|}
\hline $\begin{array}{l}\text { Authors: } \\
\text { Nelesh Dhanp } \\
\text { Dorothy L. Da } \\
\text { Oyisa Fetile } \\
\text { Kholeka Kekar } \\
\text { Kholosa N. M } \\
\text { Sphiwe F. Nhl } \\
\text { Elmain Ruiter }\end{array}$ & 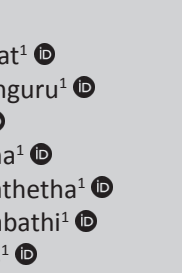 \\
\hline $\begin{array}{l}\text { Affiliations: } \\
\text { 'Department } \\
\text { Psychology an } \\
\text { Management, } \\
\text { Business and } \\
\text { University of J } \\
\text { Johannesburg }\end{array}$ & $\begin{array}{l}\text { f Industrial } \\
\text { d People } \\
\text { College of } \\
\text { conomics, } \\
\text { ohannesburg, } \\
\text { South Africa }\end{array}$ \\
\hline $\begin{array}{l}\text { Correspondin } \\
\text { Nelesh Dhanp } \\
\text { neleshd@uj.a }\end{array}$ & $\begin{array}{l}\text { g author: } \\
\text { at, } \\
\text { c.za }\end{array}$ \\
\hline $\begin{array}{l}\text { Dates: } \\
\text { Received: } 18 \text { 1 } \\
\text { Accepted: } 09 \\
\text { Published: } 28\end{array}$ & $\begin{array}{l}\text { Jov. } 2020 \\
\text { =eb. } 2021 \\
\text { Apr. } 2021\end{array}$ \\
\hline $\begin{array}{l}\text { How to cite th } \\
\text { Dhanpat, N., } \\
\text { Fetile, O., Kek } \\
\text { Mathetha, K.I } \\
\text { S.F., \& Ruiters } \\
\text { Self-managem } \\
\text { of graduate er } \\
\text { enhance work } \\
\text { SA Journal of } \\
\text { Psychology/S } \\
\text { vir Bedryfsielk } \\
47(0), \text { a1857. } \\
\text { org/10.4102/s }\end{array}$ & $\begin{array}{l}\text { is article: } \\
\text { anguru, D.L., } \\
\text { ana, K., } \\
\text { l., Nhlabathi, } \\
\text { E. (2021). } \\
\text { ent strategies } \\
\text { nployees to } \\
\text { engagement. } \\
\text { ndustrial } \\
\text { Tydskrif } \\
\text { unde, } \\
\text { https://doi. } \\
\text { ajip.v47i0.1857 }\end{array}$ \\
\hline $\begin{array}{l}\text { Copyright: } \\
\text { ( 2021. The } \\
\text { Licensee: AOS } \\
\text { is licensed un } \\
\text { Creative Comr } \\
\text { Attribution Lic }\end{array}$ & $\begin{array}{l}\text { uthors. } \\
\text { S. This work } \\
\text { ler the } \\
\text { nons } \\
\text { ense. }\end{array}$ \\
\hline Read online: & \\
\hline 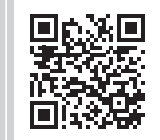 & $\begin{array}{l}\text { Scan this QR } \\
\text { code with your } \\
\text { smart phone or } \\
\text { mobile device } \\
\text { to read online. }\end{array}$ \\
\hline
\end{tabular}

Authors:

Nelesh Dhanpat ${ }^{1}$

Oyisa Fetile ${ }^{1}$

Kholeka Kekana ${ }^{1}$ (D

Sphiwe F. Nhlabathi ${ }^{1}$

Elmain Ruiters ${ }^{1}$ (1)

Affiliations:

Management, College of

Business and Economics,

University of Johannesburg,

Corresponding author:

Nelesh Dhanpat,

shd@uj.ac.za

Received: 18 Nov 2020

Accepted: 09 Feb. 2021

How to cite this article:

Dhanpat, N., Danguru, D.L.,

etile, O., Kekana, K.,

S.F., \& Ruiters, E. (2021).

Self-management strategies

of graduate employees to

enhance work engagement.

Journal of Industrial

vir Bedryfsielkunde,

47(0), a1857. https://doi.

Copyright:

(C) 2021. The Authors.

Licensee: AOSIS. This work

is licensed under the

Creative Commons

Attribution License.

mobile device

to read online.
Orientation: The hiring of graduates is valuable to organisations. It is necessary to understand the self-management behaviours they display and the behaviours required to keep them engaged.

Research purpose: The purpose of this study was to explore how self-management strategies enhance work engagement of recent graduates who find themselves in a new environment of the world of work.

Motivation for the study: Employee engagement is of both academic and practitioner interest. With organisations hiring graduates, it is valuable to understand the self-management behaviours needed to remain engaged.

Research approach/design and method: A qualitative research approach was employed through an interpretivist research paradigm. A purposive sample of 12 graduate employees (median age $=24$ ) in various fields of work were interviewed (women $=11$, men $=1$; black $=11$, coloured $=1$ ). The graduates participated in semi-structured interviews. A thematic analysis was conducted and five themes emerged.

Main findings: Through an inductive approach, the five themes that emerged concerning selfmanagement strategies used by graduates to enhance their work engagement are goal setting, self-cueing, self-observation, self-reward and self-punishment and work engagement practices.

Practical/managerial implications: Self-management strategies help to sustain an engaged workforce. Organisations that make use of graduate recruitment will largely benefit from the findings.

Contribution/value-add: There is limited research on the topic pertaining to graduate employees. Graduates remain relevant in the organisation, and hence, the study makes a contribution to theory and practice. A model is presented with recommendations for graduates and the organisation, which, when implemented, have the potential to enhance work engagement.

Keywords: self-management; work engagement; graduates; self-goal-setting; self-observation; self-cueing; self-reward; self-punishment.

\section{Introduction}

The 21st century workplace environment is changing rapidly, and therefore, organisations recruit graduates as they possess the skills required by an evolving organisation. Organisations are affected by the high increase of competition globally, and therefore aim to make use of graduates (Shivoro, Shalyefu, \& Kadhila, 2018) as they are enthusiastic about learning and developing as new employees. The labour market for graduate workers has never been so under pressure and in flux (Tholen, 2014). According to Harvey (2001), graduates are employed for their ability to learn quickly, their innovative thinking and the knowledge they contribute to the organisation. Graduates are educated, quick at acquiring new knowledge, have the necessary qualifications, skills and knowledge and have the attitudes to solve work challenges (Adams \& De Kock, 2012; Coetzee, Ferreira, \& Potgieter, 2019). They therefore become valued employees for organisations (Coetzee et al., 2019). In addition, graduates display their personal qualities and apply their skills, knowledge and practice to their work (Ismail, 2016). Therefore, organisations hire graduates to improve organisational performance.

It is necessary that an organisation ensures that it keeps new workers - including graduates satisfied, for them to stay motivated and for the organisation to retain quality employees (Yee, 2012). Employers are encouraged to mentor and train graduates, as when graduates gain 
more understanding of self-management strategies, this may enhance their work engagement (Gomez, 2017).

Self-management is defined as how employees manage their behaviour, evaluate their performance and discipline themselves when they do not reach necessary personal standards (Bakker, 2017). Self-management provides employees with strategies that may improve their performance without intervention from their managers (Unsworth \& Mason, 2016). Such strategies allow employees to structure their work, remain motivated and facilitate their behaviour, resulting in achievement of goals (Breevaart, Bakker, \& Demerouti, 2014). Work engagement does not benefit the organisation alone, but also benefits the individual employee (Brummelhuis \& Bakker, 2012). It is important that employers create a supportive work environment that will motivate employees and keep them energised and enthusiastic (Gerards, Grip, \& Baudewijns, 2018). Employees may enhance their work engagement through self-management strategies whereby they monitor and manage their behaviour without any external control (Breevaart et al., 2014).

Employee engagement is on the decline (Motyka, 2018) and there is a possible need for self-management strategies. Moreover, it is relevant for graduates entering the workplace to gain better understanding of how to become more engaged in the workplace. Therefore, the study seeks to establish the way in which self-management strategies enhance the work engagement of graduates.

The objective of this study was to explore how graduate employees initiate self-management strategies to enhance their work engagement by:

- identifying how self-management strategies are needed and may be used by graduates;

- identifying different types of self-management strategies to enhance work engagement amongst graduates and

- establishing what keeps graduates engaged at work.

Following the key research objectives of this study, the following section provides a brief literature review.

\section{Self-management strategies}

Self-management strategies assist employees to screen their own behaviour and control the choices they make within the workplace (Maria, 2015), assisting them in achieving their goals (Smith, 2017).

Self-management strategies investigate how employees self-direct and self-motivate themselves (including their emotions) at work in a manner that integrates with organisation-set policies and leads to achievement of goals (Houghton \& Neck, 2002; Zeijen, Peeters, \& Hakanen, 2018). In addition, self-management strategies can save organisations time and money and increase efficiency of work carried out by employees (Breevaart et al., 2014). The presence of self-management strategies increases task performance, innovation and creativity of employees, which increases employees' engagement and ultimately productivity in the workplace (Ghali, Habeeb, \& Hamzah, 2018). Self-management strategies consist of self-goalsetting, self-observation, self-cueing, self-reward and selfpunishment (Breevaart et al., 2014). The strategies incorporate the worker's setting goals, directing rewards, monitoring and evaluating their own performance, and making situational signals that ensure the stimulation of desired behaviours (Day \& Unsworth, 2013).

\section{Self-goal-setting}

The self-goal-setting strategy is used to set goals that are specific and challenging in order to enable individuals to be innovative and creative (Zeijen et al., 2018). Self-goalsetting will help employees to examine their long-term, intermediate, and short-term goals, also evaluating whether their goals are realistic (James \& Evans-Kasala, 2009). It is essential that employees set specific and measurable goals that give them the opportunity to compare their performance with their set goals (Maria, 2015; Van der Hoek, Groeneveld, \& Kuipers, 2018). Performance is defined as the accomplishment of goals, gauged by their effectiveness and efficiency of their attainment (Van der Hoek et al., 2018). Performance is important for organisations to ensure that employees work hard in contributing to the achievement of the organisational mission and objectives (Ying, 2004). Therefore, a goal-setting strategy is the guideline of how tasks should be carried out; it should help employees to perform and result in achieving set goals (Van der Hoek et al., 2018).

\section{Self-observation}

Self-observation is a strategy used when employees focus on their behaviour and why that behaviour exists; employees can then change their behaviour to fit their work environment and improve their performance (Breevaart et al., 2014). Employees should identify behaviour patterns and assess which behaviour is constructive and must be used, whereas destructive behaviour should be eliminated and avoided (James \& Evans-Kasala, 2009). Maria (2015) states that self-observation is self-monitoring, defined as a process whereby an individual focuses on their behaviour, thoughts, feelings, time, and environmental management, as well as identification of goals and issues preventing their accomplishment. Employees will have to self-monitor their behaviour based on their beliefs, attitudes, thoughts, character, and judgement of tasks given to them (Boz, Ayan, Eskin, \& Kahraman, 2014). Therefore, self-observation strategy determines which specific behaviour employees can use, and it provides a feedback and evaluation system that allows employees to monitor their own performance (James \& Evans-Kasala, 2009).

\section{Self-cueing}

Self-cueing refers to the system of reminders to employees about goals to be accomplished and prompt one to keep 
striving for their attainment (Bakker, 2017; James \& EvansKasala, 2009). This strategy reduces barriers that hinder employees from achieving their goals (Maria, 2015). Breevaart et al. (2014) state that self-cueing assists workers to adjust to their behaviour in order to improve their performance. Selfcueing works with the individual's personal style and includes visual, model, and environmental reminders of desired behaviour (James \& Evans-Kasala, 2009). With self-cueing, employees may continue revisiting the organisational vision and mission for a reminder of what must be accomplished (Breevaart et al., 2014). Employees can apply measures that will help them with this, such as writing notes for themselves (Mason \& Unsworth, 2016).

\section{Self-reward and self-punishment}

Self-reward entails employees' motivating themselves to strengthen their goals to achieve desired outcomes (Zeijen et al., 2018). Employees reward themselves for completing a difficult task, which serves as motivation to their work (Alper, Karakaya, \& Yilmaz, 2015). Employees can self-reward, for example, by taking themselves on a vacation or having a special dinner for a goal attained (James \& Evans-Kasala, 2009). Self-reward is linked to intrinsic motivation, which encourages employees to perform better and achieve goals (Nduka, 2016). Intrinsic motivation results when employees are more involved in completing tasks without any external control or incentives (Nduka, 2016). Intrinsic motivation is the psychological feeling an employee has towards their work, such as its becoming more meaningful, enjoyable, and the employee's performing well (Singh, 2016). Self-punishment occurs when employees evaluate their performance as poor and intend correcting this by eliminating negative behaviour and continuing to use positive behaviour (Alper et al., 2015; James \& Evans-Kasala, 2009). The two strategies lead to successful performance (Breevaart et al., 2014).

Being mindful of the brief background related to selfmanagement strategies, next follows the link of such strategies in relation to the construct called work engagement. Zeijen et al. (2018) state that work engagement inspires employees to use self-management strategies in order to set goals for themselves and observe their own emotions and behaviour within the workplace. To enhance work engagement and ensure motivation in an organisation, employees should set meaningful goals that align with organisational goals. Subsequently, employees should observe their behaviour to ensure performance improvement and positive work engagement. According to Breevaart et al. (2014), to enhance work engagement, employees do not need external control from managers; they need to self-reward and self-punish based on performance.

Self-management strategies such as self-cueing and selfreward help employees enhance their engagement in the workplace by reminding themselves why they have set their goals and what they will gain after achieving them (Breevaart et al., 2014). Self-observation and self-goal-setting strategies create a meaningful environment for employees to become innovative and creative (Breevaart et al., 2014). The self-goal and self-observation strategies help employees to change and adjust their behaviour. When the goals set by an employee do not align with those of an organisation, employees should use self-observation to change their goals and enhance their behaviour (Zeijen et al., 2018).

The five self-management strategies enhance work engagement (Breevaart et al., 2014) and can be used as a persuasive instrument for work commitment. Therefore, when employees perform at a high level and have a positive work environment, they become engaged in their job and contribute to the competitive advantage of a business (Palvalin, Van der Voordt, \& Jylhä, 2017). Self-management strategies encourage employees to set their own goals and objectives, as well as discover their own conduct and feelings, which results in employees' looking for challenges and resources, and thus the outcome of employee engagement (Zeijen et al., 2018).

\section{Self-management strategies and graduates}

Graduates entering the work environment need to make use of self-management strategies in order to monitor their own behaviour and make responsible decisions about tasks for which they are accountable (Gerards et al., 2018). Graduates require self-management strategies because such strategies increase their motivation and influence their behaviour. Also, graduates tend to be committed and perform better when given difficult tasks (Mason \& Unsworth, 2016). Coetzee et al. (2019) state that when graduates apply self-management strategies, they are able to perform under pressure, adapt to challenges, monitor their own career development and learn new skills that they can apply to their activities. Self-management strategies can assist graduates to achieve their career goals and change their behaviour in order to achieve these (Maria, 2015).

\section{Work engagement}

As the work of employees is becoming increasingly more dynamic and decentralised, organisations should encourage employees to become more proactive (Zeijen et al., 2018). Employees who are proactive are considered to display increased levels of work engagement. Employees are expected to be productive within the organisation, as well as cooperative, self-assured, perform well, and have a professional behaviour and attitude (Ram \& Prabhakar, 2011). When employees deliver outstanding and excellent performance, they tend to contribute to an organisation's competitive advantage (Richardson, 2014). Therefore, work engagement ensures that workers are mentally, physically and emotionally involved in their jobs (Bakker, 2017).

Employees who remain engaged have a positive influence on their organisation's performance and goals (Singh, 2018). It is crucial that organisations create a positive work environment and provide resources that will cause employees to become more engaged when performing their tasks (Gerards et al., 2018). However, work engagement 
may fluctuate, based on changes occurring at work and resources provided; therefore, work engagement is based on the feeling an employee has in relation to their work (Bakker \& Oerlemans, 2019). Work engagement is considered a positive, satisfying, work-related perspective, which entails three dimensions, namely, vigour, dedication and absorption (Bakker \& Albrecht, 2018).

Vigour refers to an employee's energy, determination and consistent investment of effort in their job (Rayton \& Yalabik, 2014). It is also coupled with high levels of interest by employees in their job. Even when faced with challenges, the vigorous employee is still determined to do their job (Latham \& Pinder, 2005). Bakker (2017) refers to dedication as an individual's sense of involvement to his or her work. Dedication is concerned with how employees are motivated, eager, energetic, and being exceptionally engaged in their job (Rayton \& Yalabik, 2014). Dedication is based on an individual's feeling importance from their job, feeling energetic and satisfied about the given job and feeling motivated and challenged by the job (Hook Song, Kolb, Hee, \& Kyoung, 2012). Absorption refers to a great degree of focus and separation from surrounding events and a lack of awareness of the time spent on the work (Breevaart et al., 2014). Absorption implies that employees have high levels of focus and immersion in work, whereas relaxing or taking a break is unusual, and being disengaged from one's duties is challenging for such employees (Bakker, 2017).

\section{Outcomes of engaged employees}

Engaged employees are mostly concerned with organisational success and put all their effort and enthusiasm into the achievement of a goal (Papalexandris et al., 2015).Furthermore, Papalexandris et al. argue that engaged employees carry the organisation in a positive direction, perform beyond the employer's expectations and perform their tasks with a view of organisational goals and objectives. The benefit of having employees who are engaged is that they are devoted to the organisation, motivated, committed to achieving organisational goals and they are willing to work with others to enhance organisational growth and improve their performance (Alshammari, 2015). Furthermore, engaged employees perform better and influence performance outcomes such as profitability (Singh, 2018).

In the following section, a brief outlay related to the research method that was used to explore the research objective of this study is discussed.

\section{Research method}

\section{Research approach}

The study followed a qualitative research approach (Saunders, Lewis, \& Thornhill, 2019). This approach was deemed suitable for gathering facts and thoughts about self-management strategies to enhance work engagement that individuals may have within an organisation. The study also used an inductive approach to explain ideas generated from the raw data.

\section{Research philosophy}

The study employed an interpretivist research philosophy (Saunders et al., 2019). The study focused on two research assumptions, namely, ontology and epistemology. The two assumptions assisted us to explore the impact of selfmanagement strategies on enhancing work engagement by interviewing graduates in the workplace, based on the knowledge we currently have.

\section{Population and sample}

A non-probability sampling technique was selected, which consisted of identifying and selecting individuals who were competent and knowledgeable about the research phenomenon (Etikan, Musa, \& Alkassim, 2016). Participants were selected at convenience. A sample of 12 graduates was interviewed regarding self-management strategies and work engagement. Participants were asked questions relating to the role and responsibilities graduates have within their organisations, self-management behaviours and how they remained engaged. It is known from research that saturation is reached at a point when the results are sufficient, and hence, this often occurs after 12 interviews (Box, 2014).

Table 1 provides a summary of the sample participants' biographic details. The sample comprised of 12 graduates, ranging in age from 23 to 27 years old $\left(\mathrm{M}_{\text {age }}=24\right)$. One Coloured person and 11 black people participated in the study.

\section{Research instrument}

Data were collected through the use of semi-structured interviews. The reason for using this format allowed us to

TABLE 1: Summary of the sample biographic details.

\begin{tabular}{llllll}
\hline No. & Age & Race & Gender & Job title & Industry \\
\hline 1 & 27 & Black person & Female & Polymer technologist & Manufacturing \\
2 & 24 & Black person & Female & Human resource officer & Professional body \\
3 & 23 & Black person & Female & $\begin{array}{l}\text { Talent acquisition } \\
\text { specialist }\end{array}$ & $\begin{array}{l}\text { Human resource } \\
\text { recruitment }\end{array}$ \\
\hline 4 & 23 & $\begin{array}{l}\text { Coloured } \\
\text { person }\end{array}$ & Female & $\begin{array}{l}\text { Learning and } \\
\text { development } \\
\text { administrator }\end{array}$ & $\begin{array}{l}\text { Human resource } \\
\text { management }\end{array}$ \\
\hline 5 & 23 & Black person & Female & $\begin{array}{l}\text { Sundry debtors' } \\
\text { clerk }\end{array}$ & Finance \\
\hline 6 & 25 & Black person & Female & Human capital & Manufacturing \\
\hline 7 & 24 & Black person & Female & Project coordinator & $\begin{array}{l}\text { Information } \\
\text { Technology }\end{array}$ \\
\hline 8 & 24 & Black person & Female & Software engineer & Telecommunications \\
9 & 26 & Black person & Male & Civil engineer & Engineering \\
\hline 10 & 26 & Black person & Female & Recruiting and staffing & $\begin{array}{l}\text { Human resource } \\
\text { management }\end{array}$ \\
\hline 11 & 27 & Black person & Female & Candidate attorney & Law \\
\hline 12 & 26 & Black person & Female & Senior auditor & Auditing \\
\hline
\end{tabular}


gain an understanding of the participant's perceptions of selfmanagement strategies (de Vos, Strydom, Fouche, \& Delport, 2012). Questions were open-ended for us to create a discussion between the interviewer and the graduates. The semistructured interview allowed us to use probing questions to retrieve the desired data. Examples of interview questions asked to graduates included 'Describe the type of work you $\mathrm{do}^{\prime}$ and 'Describe the challenges you find in your work; if you do experience challenges, what do you do to manage the difficulties that you encounter in your type of work'?

\section{Data collection}

Participants were contacted via email to seek participation and schedule the interview. Participants were informed that interviews would take place via video call or meeting and were asked to choose the preferred platform (viz. WhatsApp, Zoom or Skype). All interviews used an audio recording and videos were not switched on. This assisted in protecting the identity of the participant. Interviews lasted between 45 and $60 \mathrm{~min}$ on an average. All interviews took place at the convenience of the participant. Interviews were audio recorded. Two interviewers were present for each of the interviews; one conducted the questioning and the other documented field notes and also assisted with interviewing. One researcher present at the interview transcribed the data. The subsequent researcher read through the transcript whilst listening to the audio to ensure accuracy of the data. Both interviewers were visible to the participant.

\section{Data analysis and interpretation}

We used a thematic analysis developed by Braun and Clarke. They defined the process as a 'foundation in the basic skills needed to engage with other approaches to qualitative data analysis' (Braun \& Clarke, 2012, p. 57). Their six steps were followed: In the first, we read through the interviews and field notes and noted the main ideas. An outline was formed, which allowed us to compile the information received. We also listened to the audio recordings several times. According to Vaismoradi, Turunen and Bondas (2013), the second phase is generating initial codes for the data. In a systematic manner, data were coded and we noted the relevance of each code. The third phase entailed combining the codes into the prospective themes (Vaismoradi et al., 2013). In the fourth step, we ensured that coded extracts were compared with the themes and data set, and we created thematic maps. In the fifth phase, we named and defined the themes. This resulted in creating meaningful and proper informative names for each theme (Braun \& Clarke, 2006; Vaismoradi et al., 2013). According to Vaismoradi et al. (2013) producing the report is the last phase of the thematic analysis. The researchers analyse the chosen coding extracts with the research questions, and the final report of the analysis will be produced by the literature.

\section{Ethical considerations}

Aspects of trustworthiness were ensured through the criteria set out by Lincoln and Guba (1985): credibility, transferability, dependability and confirmability. Credibility is the measure of confidence in how proficiently the actual focus is addressed by the analysis of data and processes and whether the researcher properly chose appropriate participants and methods to collect information. Dependability represents the extent to which data can change and is concerned with finding ways for focusing on factors of instability of phenomena. Transferability refers to the degree to which the findings may be relatively transferred to separate settings or groups (Graneheim \& Landman, 2004). All researchers involved in the study ensured the accuracy of the transcribed data. The confirmability of the findings will be achieved by presenting the words of the participants without interpretations (Elo et al., 2014). All data collected were transcribed verbatim to express the interviewer's exact responses.

Next follows the results that emerged from the study.

In research, ensuring that ethical principles are maintained is paramount. Ethical clearance was provided by the research ethics committee at the University of Johannesburg. Participants were provided with an informed consent detailing the nature and the purpose of the study. We ensured that information provided by participants remains confidential and no names are mentioned, thus ensuring anonymity to protect the participants' identities. Participants were notified that participation was voluntary and were allowed to withdraw from the study at any time without reprisal. Interviewees were made aware that all interviews were audio-recorded for research purposes and took place through a technology-enabled platform. We will credit any information that does not belong to us through the use of appropriate referencing techniques.

\section{Results}

The purpose of this study was to explore how selfmanagement strategies enhance work engagement. Five themes and several sub-themes, as perceived by employed graduates in graduate programmes, were provided through an inductive analysis and thematic analysis. Goal setting, self-cueing, self-observation, self-reward and selfpunishment and work engagement practices are the themes identified through data analysis. Table 2 provides an overview of the themes and sub-themes.

\section{Theme 1: Goal setting}

The findings related to goal setting incorporated two subthemes, namely, task performance and career aspirations.

\section{Task performance}

This sub-theme explains the effectiveness with which an individual performs and completes given tasks. Participants stated the following:

'Every morning ... before work we have a meeting with our manager. ... she delegates specific tasks and duties that we need 
TABLE 2: Themes and sub-themes.

\begin{tabular}{|c|c|c|c|}
\hline Theme & Description & Sub-theme & Frequency \\
\hline $\begin{array}{l}\text { Theme 1: Goal } \\
\text { setting }\end{array}$ & $\begin{array}{l}\text { The planning of } \\
\text { achieving a particular } \\
\text { standard of competence } \\
\text { usually within a distinct } \\
\text { time limit. }\end{array}$ & $\begin{array}{l}\text { - Task performance } \\
\text { - Career aspirations }\end{array}$ & $\begin{array}{l}16 \\
11\end{array}$ \\
\hline $\begin{array}{l}\text { Theme 2: } \\
\text { Self-cueing }\end{array}$ & $\begin{array}{l}\text { One's awareness of } \\
\text { when and why } \\
\text { engagement persists } \\
\text { in certain behaviours. }\end{array}$ & $\begin{array}{l}\text { - Work ethics and } \\
\text { capability } \\
\text { - Work performance } \\
\text { - Rewards and } \\
\text { recognition }\end{array}$ & $\begin{array}{l}12 \\
7 \\
6\end{array}$ \\
\hline $\begin{array}{l}\text { Theme 3: } \\
\text { Self-observation: } \\
\text { Constructive } \\
\text { behaviours and } \\
\text { destructive } \\
\text { behaviours }\end{array}$ & $\begin{array}{l}\text { Behaviours that } \\
\text { intend to have a } \\
\text { purpose that is } \\
\text { beneficial and } \\
\text { behaviours that intend } \\
\text { to have a purpose that } \\
\text { can cause irreparable } \\
\text { damage. }\end{array}$ & $\begin{array}{l}\text { Destructive: } \\
\text { - Increasing work } \\
\text { pressure } \\
\text { - Lack of support and } \\
\text { feedback } \\
\text { Constructive: } \\
\text { - Efficiency } \\
\text { - Professionalism } \\
\text { - Ethical behaviour }\end{array}$ & $\begin{array}{c}17 \\
11 \\
\\
10 \\
7 \\
3\end{array}$ \\
\hline $\begin{array}{l}\text { Theme 4: Self- } \\
\text { reward and } \\
\text { self-punishment }\end{array}$ & $\begin{array}{l}\text { Reward for virtue in } \\
\text { the form of pleasure } \\
\text { and evaluating } \\
\text { behaviours that are } \\
\text { negative to enhance } \\
\text { performance. }\end{array}$ & $\begin{array}{l}\text { Self-reward: } \\
\text { - Indulgence } \\
\text { - Acknowledgement of } \\
\text { work } \\
\text { Self-punishment: } \\
\text { - Reflection } \\
\text { - Self-criticism }\end{array}$ & $\begin{array}{c}12 \\
6 \\
\\
14 \\
7\end{array}$ \\
\hline $\begin{array}{l}\text { Theme 5: Work } \\
\text { engagement } \\
\text { practices }\end{array}$ & $\begin{array}{l}\text { The influence of } \\
\text { self-management } \\
\text { strategies on } \\
\text { engagement }\end{array}$ & $\begin{array}{l}\text { - Work environment } \\
\text { - Work involvement } \\
\text { - Interaction with } \\
\text { others }\end{array}$ & $\begin{array}{c}27 \\
17 \\
6\end{array}$ \\
\hline
\end{tabular}

to complete ... to schedule and diarise all the tasks that were delegated to me to complete.' (P4, Female, Human Resource Management)

'Efficiency is one of the important goals I set for myself, getting what needs to be done, done [sic.] and doing it correctly.' (P7, Female, Information Technology)

'The type of goals that she would say it would be to manage the team independent, to be able to liaise with clients, with senior management and partners of the firm. I think those are the types of goals I'd be setting.' (P12, Female, Auditing)

\section{Career aspirations}

Career aspirations validate the desire to learn within the working space, as well as a long-term career goal, dream or plan for the near future.

\section{Participants stated the following:}

'The main goal would be to receive a promotion to manager, so that would increase the scope of work that you're doing.' (P12, Female, Auditing)

'My goal is to work hard and be in a senior level. I want to be in a senior level within two years.' (P8, Female, Telecommunications)

'So, it's almost a matter of just perfecting every task that you've been giving [sic.] and ensuring that you've learnt something from that and that you're growing.' (P11, Female, Law)

\section{Theme 2: Self-cueing}

The findings related to self-cueing incorporated three sub-themes, namely, work ethic and capability, work performance and reward and recognition.

\section{Work ethic and capability}

This theme explains the motivation one experiences by performing to the best of one's capabilities and showing a good work ethic. Participants justified this theme by stating, for instance:

'What motivates me in my job is my own work ethics, when I do something, I do it to my best of my abilities. It is a personal thing for me, I do not want to disappoint myself.' (P1, Female, Manufacturing)

'I self-motivate myself because I see myself at a certain position or point in life that I'm not at right now, so I do motivate myself by listening to other people's stories of how far they've been in their lives and the things they had to do. So, other people's stories, they motivate me, but for most, I motivate myself to where I want to be.' (P9, Male, Engineering)

'I think it would be both. As a graduate versus being qualified you are essentially concerned about getting out quality work ... and you're concerned about making sure that ... whatever the client is presenting and their financial statement [are] accurate.' (P12, Female, Auditing)

\section{Work performance}

Work performance evaluates whether an individual performs the job successfully. This sub-theme was generated based on views from participants such as:

'I [am] also trying to prove myself that I can perform the task given to me. Pressure of the work environment motivates me to perform my job.' (P7, Female, Information Technology)

'In my field it's a very competitive field. You always see what the next person is doing so if you're slacking off you feel energy that pushes you to want to do better than the next person.' (P9, Male, Engineering)

'The biggest motivation is knowing that I am doing a good job, knowing that I am getting out [a large] quantity [of] work, and just because of how important we are as auditors we need to make sure that whatever clients are putting out in the public domain is a fair representation of what is actually going on in the business.' (P12, Female, Auditing)

\section{Reward and recognition}

This last sub-theme explains the physical rewards or acknowledgements that motivate positive behaviours. Participants responded as follows:

'The commission. The commission really motivates me.' (P3, Female, Human Resource Recruitment)

'Money motivates me. What motivates me most is the reward I am given at work for performing my task, for instance, when they give me an award or if I get the employee of the week award.' (P5, Female, Finance)

'If you have a good manager, someone that you can communicate freely with, someone that you can go to with questions, ... someone there to uplift you and [who] recognises you when you have done a good job, I think it plays a big role.' (P12, Female, Auditing)

\section{Theme 3: Self-observation}

The findings related to self-observation (constructive behaviours) incorporated three sub-themes, namely, professionalism, ethical behaviour and efficiency. 


\section{Professionalism}

This theme describes the behaviour expected in the workplace. In terms of behaviours considered most necessary to perform their work, participants mentioned professionalism.

They stated the following:

'To perform my job will be professionalism. I need to maintain professionalism at the end of the day but while maintaining professionalism still being able to maintain a friendly mindset.' (P3, Female, Human Resource Recruitment)

'You have to be ethical and professional because this is a professional industry so you have to be ethical, you have to be formal and obviously you have to be respectful in all those manners.' (P9, Male, Engineering)

'Managing my time, to be consistent and having customer service. When you do not provide customers with the service that they need, the organisation goals will not be achieved.' (P5, Female, Finance)

\section{Ethical behaviour}

This sub-theme relates to the moral principles in the workplace. In addition to professionalism, participants also noted that acting ethically is another constructive behaviour required. Participant 9 had already mentioned ethics in his quote above, and went on to say:

'You have to be able to stand your ground and if you see somebody do the wrong thing...you have to be able to tell the person that what you're doing is wrong.' (P9, Male, Engineering)

\section{Other participants stated the following:}

'Ethics, I must be an ethical person. I must ensure that policies and procedures implemented are enforced. I need to lead by example, I cannot tell people to follow a certain procedure when myself I cannot follow the procedures; my ethical behaviour and moral behaviour need to form the base of all that.' (P2, Female, Professional Body)

'The biggest one would be ethical behaviour ... something that is drilled into us from day one even when we are studying for our degree.' (P12, Female, Auditing)

\section{Efficiency}

This was the third sub-theme identified in relation to constructive behaviours and entails one's ability to achieve maximum productivity with very little wasted effort or cost. Participants made comments such as:

'I must have time management and be deadline driven.' (P3, Female, Human Resource Recruitment)

'Managing my time, to be consistent, and having customer service.' (P5, Female, Finance)

'Expected to adhere to deadline and being punctual.' (P1, Female, Manufacturing)

The findings related to self-observation (destructive behaviours) incorporated two sub-themes, namely, lack of support and feedback and increasing work pressure.

\section{Lack of support and feedback}

In order for one to perform at one's best, support and feedback from management is required. A lack of support and feedback, however, was mentioned by the participants as being destructive. They stated the following:

'We work pretty significant hours. ... it takes a toll on you physically, mentally and emotionally so ... you don't have the right support system and you don't have the right tools in place that can ... really get you down.' (P12, Female, Auditing)

'Lack of support. If I failed to deliver a solution in the given time, he would tell me that I am not good enough.' (P8, Female, Telecommunications)

\section{Increasing work pressure}

A healthy workplace environment is vital in order to achieve desired outcomes. However, this may be hampered by increasing work pressure, making this a further sub-theme under destructive behaviours. Participants stated the following:

'The biggest challenge would be ... working in a really high-pressure environment ... just because of the field we are in.' (P12, Female, Auditing)

'When I first started, my company was doing a learning and development programme for 50 candidates, so I was basically just thrown in the deep end, I had to basically learn very quickly and that was essentially a challenge.' (P4, Female, Human Resource Management)

'[One of the biggest problems] I had to overcome was time management, getting many [sic.] information from different people, being able to centre myself and not getting overwhelmed by all of the information being received and still be able to prioritise and still stand up for myself.' (P3, Female, Human Resource Recruitment)

\section{Theme 4: Self-reward and self-punishment}

\section{Self-reward}

The findings related to self-reward incorporated two sub-themes, namely, indulgence and acknowledging good work.

\section{Indulgence}

In terms of self-reward, participants mentioned self-indulgence. Indulgence is the action or fact of giving in to one's desires.

\section{Participants stated:}

'I reward myself by going for shopping, sometimes I do a new hairstyle and buy myself food.' (P5, Female, Finance)

'I reward myself with getting something nice such as a handbag.' (P7, Female, Information Technology)

'I mean with a drink at the end of the day, yeah that kind of thing. Does buying myself a handbag count as rewarding myself? Um yeah. That's how I reward myself. I spend my money on me, that's the thing that I enjoy.' (P12, Female, Auditing) 


\section{Acknowledging good work}

Participants also mentioned acknowledging their own work as another form of self-reward. Acknowledging good work is to show or express recognition of one's own good performance. Participants stated:

'I kind of give myself a pat on the back. Well done for the stuff you've done, well done for this job you've done because not everybody was capable of doing this.' (P9, Male, Engineering)

'I just say well done, you did well. I just basically talk to myself and I try my best not to ... make it public that I'm actually kind of giving myself a pat on the back.' (P10, Female, Human Resource Management)

'I think the biggest thing would be just recognising that I've done a good job and feeling proud of myself, because when you've got the feeling of accomplishment you feel even more.' (P12, Female, Auditing)

\section{Self-punishment}

The findings related to self-punishment incorporated two sub-themes, namely, reflection and self-criticism.

Reflection: In terms of self-punishment, reflection (especially on mistakes on problem areas) was a common sub-theme amongst the participants, who stated, for instance:

'I always go back and see where I went wrong and see what I could have done differently.' (P1, Female, Manufacturing)

'I do not exactly reprimand myself, you know I would just reflect on what I did wrong - Why was that task ineffective? - and I would go to my manager for some clarification and some guidance to see if I can correct my mistakes.' (P4, Female, Human Resource Management)

'The best thing I always tell myself is to learn from that experience. I retain information in terms of what went wrong and where it went wrong and why it went wrong so that next time, I do not repeat the same mistake.' (P10, Female, Human Resource Management)

Self-criticism: Participants also mentioned that they were self-critical as a way of correcting negative behaviour (self-punishment). The following statements allude to this:

'I work overnight and make sure that I do not perform the mistake twice. I ask for guidance from one of my team members to avoid having to perform the task ineffectively.' (P6, Female, Manufacturing)

'I panic, stress about that but I make sure that I fix my mess. I ensure that I do not repeat the same mistake again.' (P7, Female, Information Technology)

'I think the first thing I do is to tell somebody about it and I really just tried to dig deep and remind myself that I am allowed to make mistakes and I'm not expected to be perfect all the time.' (P12, Female, Auditing)

\section{Theme 5: Work engagement practices}

The findings related to work engagement incorporated three sub-themes, namely, work environment, work involvement and interaction with others.

\section{Work environment}

This sub-theme describes the employee workplace, work equipment and work procedures. Participants mentioned how they engaged in their work environment:

'We have a gym at work. And whenever I am not in a good mood I normally go to the gym and let my anger out.' (P8, Female, Telecommunication)

'Just being on site keeps me happy ... seeing people working [in] groups and seeing people come together to solve complicated problems and tasks and just seeing how different types of mechanisms can come together.' (P9, Male, Engineering)

'Just the environment and the culture of a firm and fitting in and feeling [like] one of the people, I suppose, and also, being involved in my team and the work that we do, not feeling like I'm just assuming they are on the outside looking in but getting involved and what's being done.' (P11, Female, Law)

\section{Work involvement}

This sub-theme explains how involved participants are when performing their job. They stated:

'Learning new things kept me engaged and getting involved in new projects. Going to new areas and seeing how they do things, learn best practices from them.' (P1, Female, Manufacturing)

'Talking to the candidates, listening to how excited they are or just engaging even if the role is not right for them and still being open with them and letting them know that I will look for other roles for them.' (P3, Female, Human Resource Recruitment)

'I keep myself updated with regards to what's happening in the industry and where the industry is going.' (P10, Female, Human Resource Management)

\section{Interaction with others}

As a form of engagement, this sub-theme emphasises the interaction of employees with their clients and colleagues when performing their job. Participants stated:

'I like communicating with candidates, asking about their personal life, work life, you know, creating relationships, and that's exactly what I love doing and being a point of contact for those candidates and know that I'm making a difference in their lives.' (P4, Female, Human Resource Management)

'I love talking to candidates on the phone, especially ... to find out how they were doing, what their plans are, how they think about certain things. I especially loved to interact with candidates while we were still doing it face to face.' (P10, Female, Human Resource Management)

'I think probably getting positive feedback from a client, ... sometimes when you had a really good engagement with a client they will say, you know, thanks guys for helping us get the stuff out in a timely manner.' (P12, Female, Auditing)

Next follows a discussion to integrate the results that emerged in the study and previous theory to develop a conceptual conclusion of each theme. 


\section{Discussion}

The study sought to gain preliminary understanding of how self-management strategies enhance work engagement. The sub-objectives of the study were to identify how selfmanagement strategies are needed and used by graduates, identifying different types of self-management strategies that could be used to enhance work engagement and establishing what keeps graduates engaged in their work. Five themes regarding self-management tools used by graduates in various organisations to enhance work engagement emerged: goal setting, self-cueing, self-observation, self-reward and self-punishment and work engagement practices, each of which encompassed several sub-themes. The main themes were generated by an inductive analysis, whilst the subthemes were extracted by thematic analysis.

\section{Theme 1: Goal setting}

Self-goal-setting is the process of developing a challenging goal to specifically improve performance and assist one in being creative and innovative within the workplace (Zeijen et al., 2018). This theme incorporated two sub-themes, namely, task performance and career aspirations. The findings of this research indicated that graduates set some demanding goals for themselves related to the roles and duties they performed, and that they were dedicated to achieving these (Nadeem \& Khalid, 2018). Behaviour is influenced by goals set through maintaining effort and directing attention. The findings suggests that when graduates set and achieved career goals, this forms part of career aspirations - setting career goals leads to execution and achievement of career goals (Greco, 2016).

\section{Theme 2: Self-cueing}

Self-cueing provides individuals with reminders about the goals they set and what should be accomplished to ensure their achievement (Bakker, 2017; James \& Evans-Kasala, 2009). The findings linked to self-cueing included three subthemes, namely, work performance, work ethic and capability, reward and recognition. Work performance refers to the total expected organisational value of what people do in the organisation (Motowidlo, 2003). The study revealed that graduates working in a competitive environment and performing their work to the best of their ability reminds them of what needs to be accomplished. It can therefore be assumed that the work performance keeps graduates engaged in their work. Work ethic refers to the innate ability of work to improve character (Chasovschi, 2016). The findings demonstrated that the graduates' work ethic and capability kept them motivated at work by ensuring that they produced quality work and by maintaining the desire to progress in their careers, which raises the possibility that work ethic and capability keep graduates engaged in their work activities. It is likely that employees are being rewarded and recognised for their performance, which kept them motivated. Recognition refers to the return on the workers' effort, dedication and results, whilst reward is the material or financial expression of appreciation for employees' results
(Baskar \& Prakash Rajkumar, 2015). An implication of this is the possibility that when graduate employees are recognised and rewarded for their good performance, it keeps them motivated, which, in turn, results in increased work engagement.

\section{Theme 3: Self-observation}

Self-observation entails employees being aware of when they exhibit particular behaviours, and a self-observation strategy leads employees to change their behaviour to better their performance (Breevaart et al., 2014). The findings related to self-observation included both constructive and destructive behaviours. The sub-themes related to constructive behaviours were professionalism, ethical behaviour and efficiency. Professionalism refers to the conduct or behaviour that characterises an individual in the workplace, and includes acting in an ethical manner. The findings suggest that professionalism and ethical behaviour are expected from the graduate in order to perform the job. Efficiency was another sub-theme, referring to the ability to perform a job without wasting time or resources (Wilson, Wnuk, Silvander, \& Gorschek, 2018). The study also found that a sense of efficiency ensured that employees performed the job timeously and met deadlines.

The findings related to destructive behaviours of selfobservation included two sub-themes, namely, lack of support and feedback and increasing work pressure. Lack of feedback is inadequate information about a person's performance, and lack of support is inadequate assistance. According to James and Evans-Kasala (2009), selfobservation strategy provides a feedback evaluation system that allows employees to monitor their own performance. Involved employees show an aspiration to stay in an organisation, aim for quality outcomes and constant advancement to achieve tasks (Bhuvanaiah \& Raya, 2014). The study found that a lack of support and feedback could lead to poor performance by employees. Work pressure is related to conflicting demands in the workplace, and findings revealed that this is a challenge faced by employees. It can thus be suggested that lack of feedback, lack of support and work pressure could lead to poor performance and, in turn, a decrease in work engagement.

\section{Theme 4: Self-reward and self-punishment}

Self-reward manifests when graduates motivate themselves through rewarding themselves for good performance or completion of a difficult task; in doing, so they intend to eliminate negative behaviour (Alper et al., 2015). Self-reward behaviours are desirable, reinforced (Breevaart et al., 2014) and linked to intrinsic motivation, which encourages employees to perform better and achieve goals (Nduka, 2016). The findings related to self-reward incorporated two sub-themes, namely, indulgence and acknowledging good work. The findings indicated that self-indulgence is a desired behaviour for employees. The findings also proved that graduates reward themselves by splurging, a form of selfindulgence (Jonyo, 2015). 
Self-punishment occurs when employees evaluate their performance, and if they consider it to be negative, they intend on correcting this by eliminating negative behaviour and continuing to show positive behaviour (Alper et al., 2015; James \& Evans-Kasala, 2009). The findings related to self-punishment incorporated two sub-themes, namely, reflection and self-criticism. According to Chang (2019), reflection refers to learning from experience, and being selfcritical in finding fault with one's own actions. It appears that employees examine and analyse their performance to identify behaviours that hinder their performance, and identify where they can effect improvement. Successful performance is vital; therefore, self-reward and self-punishment strategies aim to encourage positive behaviours and prevent negative behaviours to ensure improved performance (Breevaart et al., 2014). Lastly, the findings of the study confirm that graduates evaluate their work by understanding what is required of them from their employers (Minei, Eatough, \& Cohen-Charash, 2018).

\section{Theme 5: Work engagement practices}

Work engagement practices are tools such as leadership development that enhance employee's loyalty, motivation, passion and performance to achieve organisational goals effectively (Memon, Soomro, \& Kumar, 2018). The findings suggested three sub-themes, namely, work involvement, work environment and interaction with others. Work involvement involves employees' putting all their effort into their job (Abu Aleinein, 2016). It is likely that employees could be kept engaged when they learn new things at work. Work environment encompasses the settings or conditions under which people work (Saheed \& Ireti, 2020). The study also found that the type of environment in which employees work keeps them satisfied enough to perform their work activities. Interaction with others, which includes the exchange of information and knowledge with others, also played a role in work engagement practices (Leydesdor, 2003). It is likely that communicating with their candidates and clients made employees happy and more engaged in the work. It can therefore be assumed that the employees' work environment, work involvement and interaction with others keep them engaged in their work activities.

Graduates enter the workplace with minimal skills and necessary workplace experience; hence, keeping them engaged and successful in their work should be a priority of their line managers and human resource departments. Figure 1 presents a model of self-management strategies that provides insights to graduates and organisations, and promotes work engagement practices.

Next follows the practical implications, recommendations and limitations linked with the research of self-management strategies.

\section{Practical implications}

Most large organisations have well-established graduate programmes. The findings of the study are likely to assist organisations that embark on graduate development programmes to recognise self-management behaviours present in prospective graduate applicants. Line managers who make use of graduates might find the study useful as they are likely to gain insight into self-management behaviours necessary for graduates. The level of highly engaged employees is dependent on employee behaviours; managers in organisations need to motivate graduate

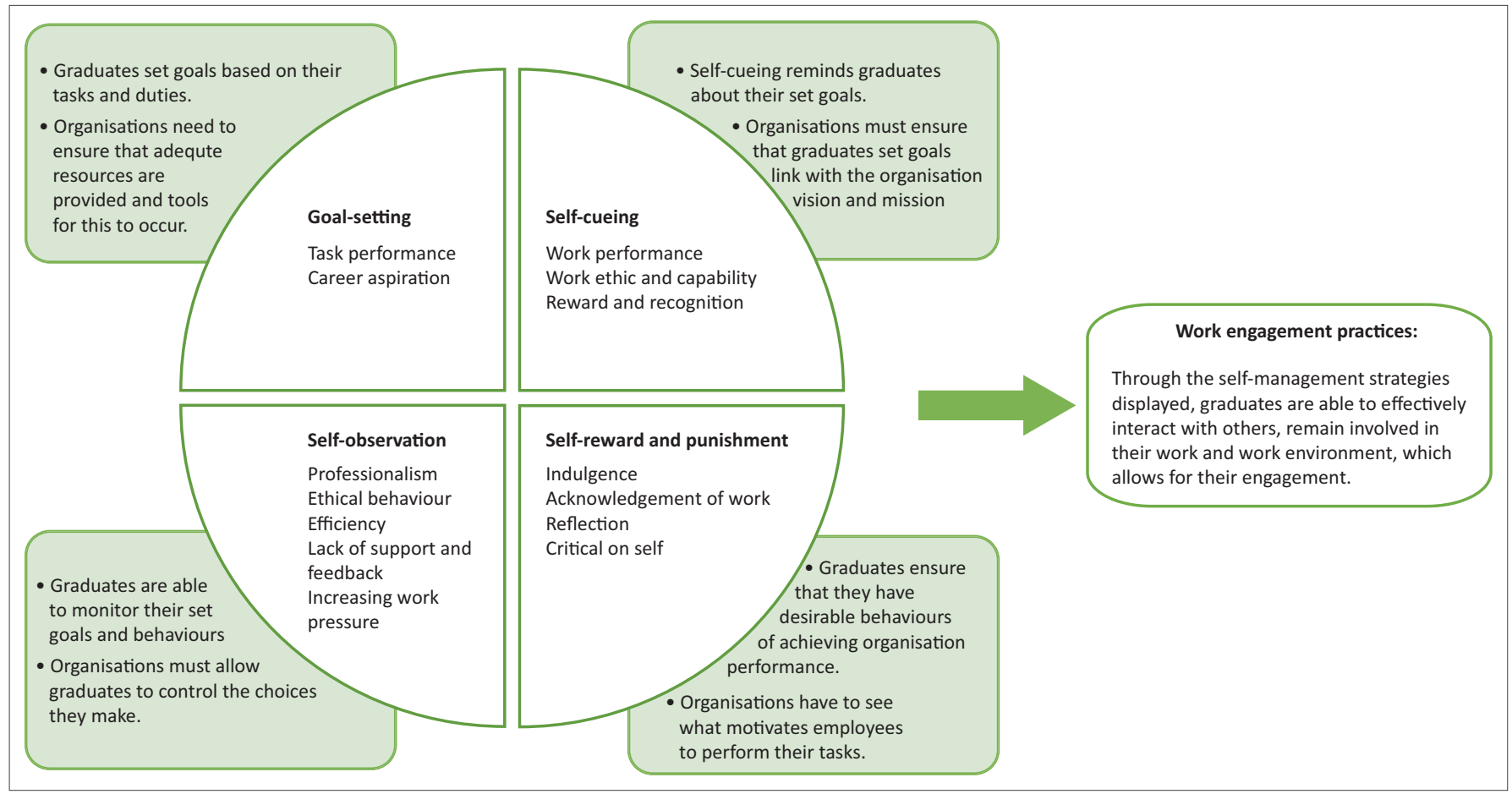

FIGURE 1: A model of self-management strategies to enhance work engagement. 
employees to exude the desirable behaviours in order to efficiently improve their work performance. Human resources should remain cognisant of the self-management behaviours used by graduates.

\section{Limitations and recommendations}

Research is never void of limitation. Because of the Covid-19 pandemic and lockdown in South Africa, interviews for our study were conducted during a period that did not allow for collecting data from graduates in a formal workplace environment and based on their experience of work traditionally; instead, the interviews were conducted virtually. As a result, technological challenges were considered a limitation. There are limited studies on selfmanagement strategies within the South African context. It is recommended that future researchers embark on investigating this concept through various designs, including quantitative studies. It would be interesting to measure self-management behaviours over time through longitudinal studies. The study should be deployed using various samples in different industries or a focus on graduates in a specific industry. It may be appropriate for future studies to use quantitative research methods so as to substantiate findings of the current research, which can be used as a point of departure within the South African context.

\section{Conclusion}

The study is preliminary in nature and provided new knowledge and insight into what keeps graduates engaged in the workplace. Through qualitative research methods, the study demonstrated that employed graduates can use certain self-management strategies to improve work engagement. Understanding how self-management strategies enhance work engagement will ensure that managers have the required knowledge to improve employees' work engagement. Therefore, this research study makes a contribution to theory and practice for graduate employees (to improve their work engagement), as well as informing managers and HR professionals how to support this. Furthermore, the study suggests that there should be more research around how and why graduates require selfmanagement strategies in order to stay engaged at work.

\section{Acknowledgements Competing interests}

The authors declare that they have no financial or personal relationships that may have inappropriately influenced them in writing this article.

\section{Authors' contributions}

N.D. supervised the study and assisted in data analysis and consolidating and finalising the manuscript. The remaining authors, D.L.D., O.F., K.K., K.N.M., S.F.N. and E.R., contributed to the writing, data collection and data analysis equally.

\section{Funding information}

This research received no specific grant from any funding agency in the public, commercial or not-for-profit sectors.

\section{Data availability}

The authors confirm that the data supporting the findings of this study are available within the article.

\section{Disclaimer}

The views and opinions expressed in this article are those of the authors and do not necessarily reflect the official policy or position of any affiliated agency of the authors.

\section{References}

Abu Aleinein, A. (2016). The impact of job involvement on job performance at UNRWA Gaza field office. Gaza: Islamic University of Gaza.

Adams, S., \& De Kock, F. (2012). The role of salient beliefs in graduates' intention to apply. SA Journal of Industrial Psychology, 41(1), 1-11. https://doi.org/10.4102/ sajip.v41i1.1223

Alper, F., Karakaya, A., \& Yilmaz, K. (2015). Relations between self-leadership and critical thinking skills. Procedia - Social and Behavioral Sciences, 207(541), 29-41. https://doi.org/10.1016/j.sbspro.2015.10.147

Alshammari, H. (2015). Workplace productivity through employee workforce engagement: A review study department of management \& information system
university of Hail, Kingdom of Saudi Arabia. International Journal of Business and university of Hail, Kingdom of
Social Science, 6(12), 156-162.

Bakker, A.B. (2017). Strategic and proactive approaches to work engagement Organizational Dynamics, 46(2), 67-75. https://doi.org/10.1016/j.orgdyn. 2017.04.002

Bakker, A.B., \& Albrecht, S. (2018). Work engagement: Current trends. Career Development International, 23(1), 4-11. https://doi.org/10.1108/CDI-11-20170207

Bakker, A.B., \& Oerlemans, W.G.M. (2019). Daily job crafting and momentary work engagement: A self-determination and self-regulation perspective. Journal of Vocational Behavior, 112, 417-430. https://doi.org/10.1016/j. jvb.2018.12.005

Baskar, P.R.K.R., \& Prakash Rajkumar, K.R. (2015). A study on the impact of rewards and recognition on employee motivation. International Journal of Science and Research, 4(11), 1644-1648. https://doi.org/10.21275/v4i11.NOV151549

Bhuvanaiah, T., \& Raya, R.P. (2014). Employee engagement: Key to organizational success. SCMS Journal of Indian Management, 11(4), 61-71. https://doi. org/10.1108/17506200710779521

Braun, V., \& Clarke, V. (2012). Thematic analysis. In H. Cooper, P.M. Camic, D.L. Long, A.T. Panter, D. Rindskopf, \& K.J. Sher (Eds.), APA handbooks in psychology ${ }^{\circledast}$. APA handbook of research methods in psychology, Vol. 2. Research designs: Quantitative, qualitative, neuropsychological, and biological (pp. 57-71). American Psychological Association, Washington, DC.

Box, I. (2014). How many interviews are needed to in a qualitative research? Is there any rule or popular practice? Management Journal, 7(1), 43-56.

Boz, I.T., Ayan, A., Eskin, I., \& Kahraman, G. (2014). The effect of the level of selfmonitoring on work engagement and emotional exhaustion: A research on small and medium size enterprises (SMEs). Procedia-Social and Behavioral Sciences, 150, 1080-1089. https://doi.org/10.1016/j.sbspro.2014.09.122

Braun, V., \& Clarke, V. (2006). Teaching thematic analysis: Overcoming challenges and developing in strategies for effective learning. Qualitative Research in Psychology, 3(2), 77-101. https://doi.org/10.1191/1478088706QP0630A

Breevaart, K., Bakker, A.B., \& Demerouti, E. (2014). Daily self-management and employee work engagement. Journal of Vocational Behavior, 84(1), 31-38. https://doi.org/10.1016/j.jvb.2013.11.002

Brummelhuis, L.L., \& Bakker, A.B. (2012). Staying engaged during the week: The effect of off-job activities on next day work engagement. Journal of Occupational Health Psychology, 17(4), 445-455. https://doi.org/10.1037/a0029213

Chang, B. (2019). Reflection in learning. Online Learning, 23(1), 95-110. https://doi org/10.24059/olj.v23i1.1447

Chasovschi, C. (2016). Perspectives on work ethic. An intercultural approach. The USV Annals of Economics and Public Administration, 16(3), 93-98.

Coetzee, M., Ferreira, N., \& Potgieter, I.L. (2019). Employer requirements and employability mindset influencing graduate workers' self confidence in gaining employment. African Journal of Career Development, 1(1), 2617-7471. https:// doi.org/10.4102/ajcd.v1i1.4

Day, D., \& Unsworth, K. (2013). Goals and self-regulation: Emerging perspectives across levels and time. In E.A. Locke \& G.P. Latham (Eds.), New developments in goal setting and task performance (pp. 158-176). New York, NY: Routledge. 
De Vos, A.S., Delport, C.S.L., Fouche, C., \& Strydom, H. (2011). Research at grass roots: For the social sciences and human service professions. Pretoria: Van Schaik Publishers.

Elo, S., Kääriäinen, M., Kanste, O., Pölkki, T., Utriainen, K., \& Kyngäs, H. (2014). Qualitative content analysis: A focus on trustworthiness. Sage Open, 4(1), 1-10. https://doi.org/10.1177/2158244014522633

Etikan, I., Musa, S.A., \& Alkassim, R.S. (2016). Comparison of convenience sampling and purposive sampling. American Journal of Theoretical and Applied Statistics, 5(1), 1-4. https://doi.org/10.11648/j.ajtas.20160501.11

Gerards, R., De Grip, A., \& Baudewijns, C. (2018). Do new ways of working increase work engagement? Personnel Review, 47(2), 517-534. https://doi.org/10.1108/ PR-02-2017-0050

Ghali, B.A.A., Habeeb, L.M., \& Hamzah, K.D. (2018). Self-management and its relation to organizational excellence. International Journal of Engineering and Technology to organizational excellence. International Journal of Engineering
(UAE), 7(4), 47-50. https://doi.org/10.14419/ijet.v7i4.7.20378

Gomez, S.J. (2017). Self-management skills of management graduates. International Journal of Research in Management \& Business Studies, 4(3), 40-45.

Graneheim, U.H., \& Landman, B. (2004). Qualitative content analysis in nursing research: Concepts, procedures and measures to achieve trustworthiness. Journal of Nurse Education Today, 24(1), 105-112. https://doi.org/10.1016/j.nedt.2003.10.001

Greco, L.M. (2016). Professional identification and career goals: Goal setting in the role transition process. lowa Research Online Theses, 1(1), 146

Harvey, L. (2001). Defining and measuring employability. Quality in higher education, 7(2), 97-109.

Hook Song, J., Kolb, J.A., Hee Lee, U., \& Kyoung Kim, H. (2012). Role of transformational leadership in effective organizational knowledge creation practices: Mediating effects of employees' work engagement. Human Resource Development Quarterly, 23(1), 65-101. https://doi.org/10.1002/hrdq.21120

Houghton, J.D., \& Neck, C.P. (2002). The revised self-leadership questionnaire. Journal of Managerial Psychology, 17(8), 672-692. https://doi.org/10.1108/026839 40210450484

James, A.M., \& Evans-Kasala, M. (2009). Self-leadership and self-regulated learning An investigation of theoretical relationships. Journal of Business and Leadership 5(1), 59-67.

Jonyo, E.O. (2015). Effects of occupational stress on work performance of police officers in Nakuru police division, Kenya. IOSR Journal of Computer Engineering, 17(6), 61-88.

Ismail, S. (2016). Graduate employability capacities, self-esteem and career adaptability among South African young adults. SA Journal of Industrial Psychology, 43(0), 1-10. https://doi.org/10.4102/sajip.v43i0.1396

Latham, G.P., \& Pinder, C.C. (2005). Work motivation theory and research at the dawn of the twenty-first century. Annual Review of Psychology, 56, 485-516. https:// doi.org/10.1146/annurev.psych.55.090902.142105

Leydesdor, Ÿ.L. (2003). Interaction versus action in Luhmann's sociology of communication. Rethinking Communicative Interaction: New Interdisciplinary Horizons, 116, 2-20.

Lincoln, Y.S., \& Guba, E.G. (1985). Naturalistic inquiry. Newbury Park, CA: Sage.

Maria, K. (2015). Oulu business school. Department of Management and International Business, 1(1), 1-81.

Mason, C.M., \& Unsworth, K.L. (2016). Self-concordance strategies as a necessary condition for self-management. Journal of Occupational and Organizational Psychology, 89(4), 711-733. https://doi.org/10.1111/joop.12149

Memon, S.B., Soomro, S.B., \& Kumar, S. (2018). Assessing the work engagement, work practices and work performance in banks. Journal of Administrative and Business Studies, 4(3), 165-184.

Minei, E.M., Eatough, E.M., \& Cohen-Charash, Y. (2018). Managing illegitimate task requests through explanation and acknowledgment: A discursive leadership
approach. Management Communication Quarterly, 32(3), 374-397. https://doi. approach. Management Communica
org/10.1177/0893318918755506

Motowidlo, S.J. (2003). Job performance. In W.C. Borman, D.R. Ilgen, \& R.J. Klimoski (Eds.), Handbook of psychology: Vol. 12. Industrial and organizational psychology (pp. 39-53). New York: Wiley.

Motyka, B. (2018). Employee engagement and performance: A systematic literature review. International Journal of Management and Economics, 54(3), 227-244. https://doi.org/10.2478/ijme-2018-0018
Nadeem, F., \& Khalid, R. (2018). The relationship of gender role attitudes with career aspirations and career choices among young adults. Pakistan Journal of Psychological Research, 33(2), 455-471.

Nduka, O. (2016). Employee motivation and performance. Degree dissertation. Centria University of Applied Sciences. Retrieved from https://core.ac.uk/ download/pdf/80992496.pdf

Papalexandris, N., Galanaki, E., Swathi, S., Iqbal, A., Studies, B., Mahomed, Y., ... Pansari, A. (2015). Employee engagement: A conceptual framework. The International Journal of Business \& Management, 5(1), 639-649.

Palvalin, M., Van der Voordt, T., \& Jylhä, T. (2017). The impact of workplaces and selfmanagement practices on the productivity of knowledge workers. Journal of Facilities Management, 15(4), 423-438. https://doi.org/10.1108/JFM-03-20170010

Ram, P., \& Prabhakar, G. (2011). The role of employee engagement in work related outcomes. Interdisciplinary Journal of Research in Business, 1(3), 47-61.

Rayton, B.A., \& Yalabik, Z.Y. (2014). Work engagement, psychological contract breach and job satisfaction. International Journal of Human Resource Management, 25(17), 2382-2400. https://doi.org/10.1080/09585192.2013.876440

Richardson, F.W. (2014). Enhancing Strategies to improve workplace performance. Doctoral dissertation. Retrieved from https://scholarworks.waldenu.edu/ dissertations/106

Saheed, O.O., \& Ireti, O.A. (2020). Employees demography and team-playing behaviour of bank workers in ljebu Ode, Ogun State, Nigeria. Journal of Management and Research, 7(1), 24-51. https://doi.org/111.68.103.197

Saunders, M., Lewis, P., \& Thornhill, A. (2019). Research methods for business students (8th edn.). Pearson: Harlow.

Shivoro, R.S., Shalyefu, R.K., \& Kadhila, N. (2018). Perspectives on graduate employability attributes for management science students. South African Journa of Higher Education, 32(1), 216-232. https://doi.org/10.20853/32-1-1578

Singh, R. (2016). The impact of intrinsic and extrinsic motivators on employee engagement in information organizations. Division of Library and Information Science, 57(2), 197-206. https://doi.org/10.12783/issn.2328-2967/57/2/11

Singh, S. (2018). The impact of employee engagement on organisational performance-a case of an insurance brokerage company in Gauteng. IOSR Journal of Business and Management, 20(6), 66-76. https://doi.org/10.9790/487X-2006076676

Smith, J.K. (2017). Management strategies to improve employee engagement in the credit union industry. ProQuest dissertations and theses. Minnesota: Walden University.

Tholen, G. (2014). The changing nature of the graduate labour market. New York, NY: Palgrave and Macmillan.

Unsworth, K.L., \& Mason, C.M. (2016). Self-concordance strategies as a necessary condition for self-management. Journal of Occupational and Organizational Psychology, 89(4), 711-733. https://doi.org/10.1111/joop.12149

Van der Hoek, M., Groeneveld, S., \& Kuipers, B. (2018). Goal setting in teams: Goal clarity and team performance in the public sector. Review of Public Personnel Administration, 38(4), 472-493. https://doi.org/10.1177/0734371X16682815

Vaismoradi, M., Turunen, H., \& Bondas, T. (2013). Content analysis and thematic analysis: Implications for conducting a qualitative descriptive study. Nursing and Health Science, 15(5), 398-405. https://doi.org/10.111/nhs.1204

Wilson, M., Wnuk, K., Silvander, J., \& Gorschek, T. (2018). A literature review on the effectiveness and efficiency of business modeling. e-Informatica Software Engineering Journal, 12(1), 265. https://doi.org/10.5277/e-Inf180111

Yee, S. (2012). A survey of factors influencing employee engagement. Doctoral dissertation. PhD thesis. George Town: University Sains Malaysia.

Ying, Z.Y. (2004). The impact of performance management system on employee performance. Masters dissertation. University of Twente. Retrieved from https:// essay.utwente.nl/62260/1/Daisy-master_thesis.pdf

Zeijen, M.E.L., Peeters, M.C.W., \& Hakanen, J.J. (2018). Workaholism versus work engagement and job crafting: What is the role of self-management strategies? Human Resource Management Journal, 28(2), 357-373. https://doi.org/ 10.1111/1748-8583.12187 